\title{
Profile of Trace Elements in Selected Medicinal Plants of North East India
}

\author{
R. K. Bhanisana Devi* and HNK Sarma \\ Department of Physics, Manipur University, Canchipur, Imphal 795003, India.
}

\begin{abstract}
Trace elements like $\mathrm{Mn}, \mathrm{Fe}, \mathrm{Cu}, \mathrm{Zn}$ and major elements $\mathrm{K}$ and $\mathrm{Ca}$ were quantified in ten selected medicinal plants of North East India by using Proton Induced X-ray Emission (PIXE) technique. No toxic heavy metals such as $\mathrm{As}, \mathrm{Hg}, \mathrm{Pb}$ and $\mathrm{Cd}$ were detected. The concentration (ppm) of the elements in the studied plants was found to be as follows: manganese (10 to1800), iron(27 to 836), copper(6 tol40), zinc(10 to 160), potassium(14120 to 76950) and calcium(1660 to 32030). The levels of trace metals present in the plants was found to be beyond the safety standards of WHO in edible plants but around the permissible range for consumed medicinal herbs as defined for different countries.
\end{abstract}

Key words: Medicinal plants, PIXE, trace elements, safety standards.

\section{Introduction}

Therapeutic plants have always been valued as a means of treatment for various ailments in ancient times and have played important role as beacon light in the discovery of the modern day medicines with novel chemical constituents. The efficacy of medicinal plants for curative purposes is often accounted for in terms of their organic constituents like essential oils, vitamins, glycosides and other bio constituents. It has been an established fact that over dose or prolonged ingestion of medicinal plants may lead to chronic accumulation of different elements which cause to various health problems (WHO, 1992 ; Sharma et al., 2009). Essential metals can also produce toxic effects when the metal intake is in high concentration, whereas non essential metals are toxic even in very low concentration for human health (Sheded GM et al,. 2006; Koe H. and Sari H 2009; Basgel S. and Erdemoglu SB 2006). The concentration of trace elements in medicinal herbs beyond permissible limit is a matter of great concern to public safety all over the world (Calixto, B.J., 2000). In North Eastern part of India, medicinal plants have been used by the local physicians to treat various ailments for centuries. The medicinal herbs which form the raw materials for the finished products of herbal treatments are neither controlled nor popularly regulated by quality assurance parameters. The World Health Organization (WHO) recommends that medicinal plants which form the raw materials for the finished products may be checked for the presence of heavy metals. Plants may absorb heavy metals from soil, water or air. The ability of plants to selectively accumulate essential element varies in different species and is subjected to certain geochemical characteristics depending on the type of soil (Khan et al., 2008). In this context, the quantization of elemental contents of medicinal plants of North Eastern India is very important and need to be screened for their control.

The objective of the present study is to determine the trace and major elements present in the ten selected medicinal plants of North East India and their levels. A comparative bio-constituents statement of the elements findings in accordance with international safety standards is reported in this paper.

\section{Materials and Methods}

Ten selected medicinal plants growing in North East India namely Meriandra bengalensis, Plectranthus ternifolious, Oscimum gratissimum, Acorus calamus, Aloe barbadensis, Vinca rosea, Adhatoda vasica, Plantago erosa, Mimosa pudica, and Alpinia zerumbet were collected for elemental analysis. Table1 summarizes pharmacognostic features of the selected medicinal herbs used as herbal remedy. The fresh plants were thoroughly washed with distilled water and dried in an oven at $60^{\circ} \mathrm{C}$ for about $48 \mathrm{hrs}$. The dried samples were finely ground into powder by using an agate mortar. 
Table -1. Pharmacognostic Features of the studied Plants.

\begin{tabular}{|c|c|c|c|c|}
\hline Sl.No. & $\begin{array}{l}\text { Family/ } \\
\text { Plant Species }\end{array}$ & Common Name & Part used & Medicinal Properties \\
\hline 1 & $\begin{array}{l}\text { Labiatae } \\
\text { Meriandra } \\
\text { bengalensis }\end{array}$ & $\begin{array}{l}\text { Kanghuman }(\mathrm{M}) \\
\text { Kafurkapat }(\mathrm{H} \& \mathrm{~B})\end{array}$ & Leaves & $\begin{array}{l}\text { Antiseptic,astringent,carminative and tonic for } \\
\text { reducing high blood pressure }\end{array}$ \\
\hline 2 & $\begin{array}{l}\text { Labiatae } \\
\text { Plectranthus } \\
\text { ternifolius }\end{array}$ & Khoiju (M) & Leaves & $\begin{array}{l}\text { Antiseptic, stimulant and for treating skin } \\
\text { diseases }\end{array}$ \\
\hline 3 & $\begin{array}{l}\text { Lamiaceae } \\
\text { Ocimum gratissimum }\end{array}$ & Ram tulsi (M,H\&B) & Whole plants & $\begin{array}{l}\text { Antiseptic, digestive, dermulcent, tonic, } \\
\text { antibacterial and blood coagulant }\end{array}$ \\
\hline 4 & $\begin{array}{l}\text { Araceae } \\
\text { Acorus calamus }\end{array}$ & $\begin{array}{l}\text { Okhidak (M), Bach } \\
(\mathrm{H} \& \mathrm{~B})\end{array}$ & Rhizome & $\begin{array}{l}\text { Emetic, Stomachic, colic, remittent fever, } \\
\text { dysentery, insectifuse, snake bite, epilepsy, } \\
\text { glandular and abdominal tumour, and mental } \\
\text { ailments }\end{array}$ \\
\hline 5 & $\begin{array}{l}\text { Liliaceae } \\
\text { Aloe barbadensis }\end{array}$ & $\begin{array}{l}\text { Ghritakumari (M\&B), } \\
\text { Ghee- Kunvar(H) }\end{array}$ & Stem & Cathartic, boils, spleen and liver diseases \\
\hline 6 & $\begin{array}{l}\text { Apocynaceae } \\
\text { Vinca rosea }\end{array}$ & Vinca $(\mathrm{M}, \mathrm{H} \& \mathrm{~B})$ & Leaves & Anti cancer properties \\
\hline 7 & $\begin{array}{l}\text { Acanthaceae } \\
\text { Adhatoda vasica }\end{array}$ & $\begin{array}{l}\text { Nongmakha angouba } \\
(\mathrm{M}) \text {, Aruha }(\mathrm{H}) \text {; Basak } \\
\text { (B) }\end{array}$ & Leaves & $\begin{array}{l}\text { Bronchial congestion, jaundice, asthma, } \\
\text { muscular pains and rheumatic complaints. }\end{array}$ \\
\hline 8 & $\begin{array}{l}\text { Plantaginaceae } \\
\text { Plantago erosa }\end{array}$ & Yempat (M) & Whole plant & $\begin{array}{l}\text { Antiseptic, antibacterial, anti-inflammatory, } \\
\text { dysentery, diarrhea, constipation and genito- } \\
\text { urinary tract complaints }\end{array}$ \\
\hline 9 & $\begin{array}{l}\text { Mimosaceae } \\
\text { Mimosa pudica }\end{array}$ & $\begin{array}{l}\text { Kangphal ikaithabi } \\
(\mathrm{M}), \quad \text { Lajwanti } \\
(\mathrm{H}), \text { Nilajban } \\
\text { (A),Lajiabati (B) }\end{array}$ & Whole plant & Uterine pains after delivery, piles and boils \\
\hline 10 & $\begin{array}{l}\text { Zingiberaceae } \\
\text { Alpinia zerumbet }\end{array}$ & $\begin{array}{l}\text { Kanghu(M), } \\
\text { Punnagchampa (B) }\end{array}$ & Rhizomes & $\begin{array}{l}\text { Stimulant, carminative, anti tubercular, } \\
\text { bronchitis, rheumatism, diarrhea and vomiting }\end{array}$ \\
\hline
\end{tabular}

Symbol codes: M-Manipuri, B- Bengali, H- Hindi, A-Assamese.

The powdered samples were mixed with high purity graphite powder in the ratio $4: 1$ by weight. The mixture were thoroughly ground and homogenized with binder $200 \mu \mathrm{l}$ of $2 \mathrm{wt} \%$ polyvinyl alcohol and pressed into pellets of $2 \mathrm{~mm}$ thickness and $13 \mathrm{~mm}$ diameter with a pressure of $30 \mathrm{kNm}^{-2}$. Pellets of certified reference materials cabbage (GBW 08504, China) and wheat flour (8436 MS Dept. of Comm. NIST Gaithersburg MD 20899) were also prepared with the same procedure for standardization of the PIXE set up. Proton beam of energy $2.5 \mathrm{MeV}$ from the $3 \mathrm{MV}$ Tandetron accelerator facility at National Centre for Compositional Characterization of Materials (CCCM), Department of Atomic Energy (DAE) Hyderabad, Government of India, collimated to a beam of $3 \mathrm{~mm}$ diameter was used to irradiate the targets (samples) for PIXE experiments. The irradiation was carried out under vacuum $\left(10^{-6}\right.$ torr). PIXE measurements were carried out with a maximum beam current of $10^{-8}$ ampere. A planar high purity germanium (HPGe) detector (Eurisys Measures Type EGX $100-01, \mathrm{Be}$ window thickness $40 \mu \mathrm{m}, \mathrm{FWHM}$ of $150 \mathrm{eV}$ at $5.9 \mathrm{keV}$ ) placed at $45^{\circ}$ to the beam axis was used to determine X-ray peak energies and intensities. To attenuate the Bremsstrahlung background and dominant low energy X-ray peaks, a mylar of thickness $40 \mu \mathrm{m}$ was used as an absorber in front of the detector. The spectral data were analyzed using GUPIX software package which provides non linear least square fitting of the spectrum and converts raw spectral data into elemental concentration.

\section{Results and Discussion}

The result analysis of the levels of trace elements present in the selected plants is discussed in this section and the concentration of $\mathrm{Mn}, \mathrm{Fe}, \mathrm{Cu}, \mathrm{Zn}, \mathrm{K}$ and $\mathrm{Ca}$ in the plants is presented in table 2. PIXE spectrum of one of the plants is shown in fig. 1.

Table 2. Elemental Concentration (ppm) of Ten Selected Medicinal Plants of North East India

\begin{tabular}{|l|l|l|l|l|l|l|}
\hline Plant Species & Mn & Fe & Cu & Zn & K & Ca \\
\hline $\begin{array}{l}\text { Meriandra } \\
\text { bengalensis }\end{array}$ & $10 \pm 0.82$ & $70 \pm 4.08$ & $10 \pm 1.63$ & $10 \pm 2.4$ & $16380 \pm 20.41$ & $3660 \pm 9-79$ \\
\hline $\begin{array}{l}\text { Plectranthus } \\
\text { ternifolius }\end{array}$ & $30 \pm 2.44$ & $108 \pm 4.1$ & $6 \pm 2.44$ & $10 \pm 0.81$ & $15270 \pm 8.98$ & $7660 \pm 4.89$ \\
\hline $\begin{array}{l}\text { Oscimum } \\
\text { gratissimum }\end{array}$ & $75 \pm 4.89$ & $183 \pm 8.98$ & $140 \pm 6.53$ & $11 \pm 3.26$ & $14570 \pm 11.43$ & $14020 \pm 15.51$ \\
\hline $\begin{array}{l}\text { Acorus } \\
\text { calamus }\end{array}$ & $70 \pm 1.63$ & $27 \pm 2.45$ & $20 \pm 0.81$ & $15 \pm 1.63$ & $15530 \pm 12.247$ & $1660 \pm 8.98$ \\
\hline $\begin{array}{l}\text { Aloe } \\
\text { barbadensis }\end{array}$ & $20 \pm 0.82$ & $63 \pm 4.08$ & $6 \pm 1.63$ & $30 \pm 2.45$ & $30440 \pm 14.69$ & $5440 \pm 10.61$ \\
\hline
\end{tabular}


Profile Of Trace Elements In Selected Medicinal Plants Of North East India

\begin{tabular}{|l|l|l|l|l|l|l|}
\hline Vinca rosea & $90 \pm 2.45$ & $150 \pm 4.89$ & $10 \pm 2.45$ & $50 \pm 3.26$ & $41280 \pm 11.43$ & $19300 \pm 13.1$ \\
\hline $\begin{array}{l}\text { Adhatoda } \\
\text { vasica }\end{array}$ & $54 \pm 6.53$ & $42 \pm 3.26$ & $7 \pm 1.63$ & $70 \pm 5.72$ & $20650 \pm 13.1$ & $13240 \pm 14.7$ \\
\hline Plantago erosa & $66 \pm 4.89$ & $836 \pm 9.8$ & $50 \pm 2.45$ & $160 \pm 5.72$ & $41070 \pm 8.98$ & $32030 \pm 7.35$ \\
\hline $\begin{array}{l}\text { Mimosa } \\
\text { pudica }\end{array}$ & $80 \pm 2.45$ & $50 \pm 1.26$ & $7 \pm 0.82$ & $20 \pm 2.45$ & $14120 \pm 5.7$ & $6730 \pm 10.6$ \\
\hline $\begin{array}{l}\text { Alpinia } \\
\text { zerumbet }\end{array}$ & $1800 \pm 10.61$ & $230 \pm 5.7$ & $20 \pm 1.63$ & $60 \pm 3.26$ & $76950 \pm 13.9$ & $4290 \pm 9.8$ \\
\hline
\end{tabular}

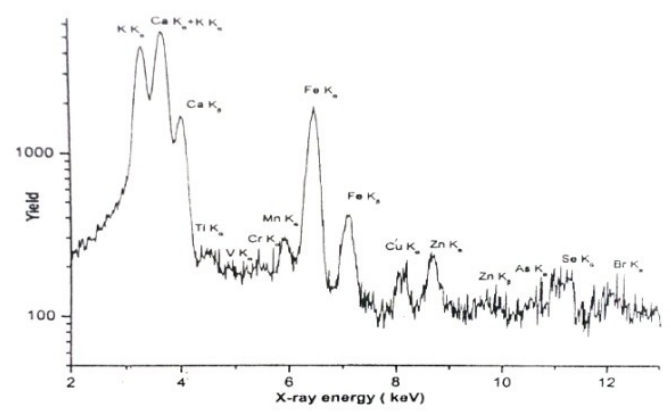

Fig. 1 PIXE Spectrum of a medicinal plant (Meriandra bengalensis)

\section{Manganese}

The highest concentration of $\mathrm{Mn}$ in the studied plants was found in Alpinia zerumbet (1800 ppm), followed by Vinca rosea (90 ppm), Mimosa pudica ( $80 \mathrm{ppm}$ ) Oscimum gratissimum (75 ppm), Acorus calamus $(70 \mathrm{ppm})$, Plantago erosa $(66 \mathrm{ppm})$, Adhatoda vasica $(54 \mathrm{ppm})$, Plectranthus ternifolius (30 ppm), Aloe barbadensis $(20 \mathrm{ppm})$ and Meriandra bengalensis $(10 \mathrm{ppm})$ (Table2). For medicinal plants the WHO (FAO/WHO., 1984) limit has not yet been established for Mn. The range of Mn concentration in selective medicinal plants of Egypt was between $44.6 \mathrm{ppm}$ to $339 \mathrm{ppm}$ (Jabeen et al, 2010). The concentration of all the selected ten medicinal plants under the present study is in the range of $10 \mathrm{ppm}$ to $1800 \mathrm{ppm}$, indicating that all the concentration of $\mathrm{Mn}$ in the plants studied is around the normal range except in Alpinia zerumbet which shows abnormally high concentration of Mn visa-vis Egyptian variety. Mn is essential in normal reproductive functions and normal functioning of the central nervous system. Its deficiency causes myocardial infection and other cardiovascular diseases and also disorder of bony cartilaginous growth in children and rheumatic arthritis in adults (Khan et al., 2008).

Iron

Fe is most prominent in Plantago erosa ( $836 \mathrm{ppm}$ ) followed by Alpinia zerumbet (230 ppm), Oscimum gratissimum (183 ppm), Vinca rosea (150 ppm), Plectranthus ternifolius (108 ppm), Meriandra bengalensis (70 $\mathrm{ppm}$ ), Aloe barbadensis (63 ppm), Mimosa pudica (50 ppm), Adhatoda vasica (42 ppm), and Acorus calamus(27 $\mathrm{ppm})$. The range of $\mathrm{Fe}$ in the studied plants was lowest in Acorus calamus(27 ppm) and highest in Plantago erosa (836 ppm) (Table 2). The permissible limit set by FAO/WHO( FAO/WHO., 1984) in edible plants was 20 ppm. After comparison of metal limit in the studied plants with those proposed by FAO/WHO (FAO/WHO., 1984) it was found that all plants under the present study have iron above this limit. However for medicinal plants the WHO (FAO/WHO., 1984) limit has not yet been established for iron. The range of iron in selective medicinal herbs of Egypt in the study carried out was between $261 \mathrm{ppm}$ to $1239 \mathrm{ppm}$ (Jabeen et al., 2010). The concentration of $\mathrm{Fe}$ in the selected ten studied plants is around the normal range for the element when compared with the medicinal herbs of Egypt. Fe is necessary for the formation of haemoglobin and also plays an important role in oxygen and electron transfer in human body. Its deficiency causes gastrointestinal infection, anaemia, nose bleeding and myocardial infection (Ullah et al.,2012).

\section{Copper}

The presence of copper is most significant in Oscimum gratissimum (140 ppm), followed by Plantago erosa ( $50 \mathrm{ppm})$, Alpinia zerumbet and Acorus calamus $(20 \mathrm{ppm})$, Meriandra bengalensis and Vinca rosea (10 ppm), Adhatoda vasica and Mimosa pudica (7 ppm), Plectranthus ternifolius and Aloe barbadensis (6 ppm). The lowest concentration of copper observed was $6 \mathrm{ppm}$ in Plectranthus ternifolius, Aloe barbadensis and highest concentration was recorded as $140 \mathrm{ppm}$ in Oscimum gratissimum (Table2). The permissible limit set by FAO /WHO for edible plants was $3.00 \mathrm{ppm}$ ( Jabeen et al., 2010). After comparision of metal limit in the studied plants with those proposed by FAO/WHO(FAO/WHO., 1984) it was found that all plants accumulated $\mathrm{Cu}$ above this limit. However, for medicinal herbs the WHO (FAO/WHO., 1984) limit has not yet been established for copper. In medicinal plants the permissible limit of copper set by China and Singapur were $20 \mathrm{ppm}$ and 150 
ppm respectively ( WHO, 2005). The selected ten herbs were found to have permissible limits of copper around the normal range set by China and Singapur. The range of copper contents in the 50 medicinally important leafy materials growing in India was $17.6 \mathrm{ppm}$ to $57.3 \mathrm{ppm}$ ( Jabeen et al., 2010). Copper is essential for proper functioning of organs and metabolic processes. Excess copper intake causes stomach upset, nausea and can lead to tissue injury and disease. Copper deficiency results in anemia, skin and hair depigmentation, thyroid disorders.

\section{Zinc}

$\mathrm{Zn}$ is most prominent in Plantago erosa( $160 \mathrm{ppm})$ followed by Adhatoda vasica (70 ppm), Alpinia zerumbet (60 ppm), Vinca rosea (50 ppm), Aloe barbadensis (30 ppm), Mimosa pudica( $20 \mathrm{ppm})$, Acorus calamus (15 ppm), Oscimum gratissimum (11 ppm), Plectranthus ternifolius and Meriandra bengalensis (10 ppm)( Table 2). The permissible limit set by FAO/WHO in edible plants was $27.4 \mathrm{ppm}$. The zinc concentration in the studied plants ranges between $10 \mathrm{ppm}$ to $160 \mathrm{ppm}$ compared to $27.4 \mathrm{ppm}$ permissible limit set by FAO/WHO ( WHO, 2005) in edible plants. Zinc is an essential trace element and plays an important role in various cell processes, normal growth, brain development, behavioral response, bone formation and wound healing. Zinc deficiency results in retardation of growth in children, low blood sugar, brain disorder, high blood cholesterol, poor sense of taste and smell.

\section{Potassium}

The range of K concentration in the studied plants varied between $76950 \mathrm{ppm}$ in Alpinia zerumbet and $14120 \mathrm{ppm}$ in Mimosa pudica (Table 2). All the studied plants show high K content as compared to the rest elements in trace levels and our results coincided with previous studies on medicinal herbs( Ozcan MM et al., 2007 and] Abdul Ghani et al., 2012). Potassium is necessary for proper functioning of our body system. It maintains the electrolyte balance, manages blood pressure, keeps heart functioning properly, and enhances muscle control, growth and health of the body cells. Its deficiency can lead to variety of mental and physical problems.

\section{Calcium}

The Ca content is highest in Plantago erosa with 32030 ppm and lowest in Acorus calamus(1660 ppm). High concentration of $\mathrm{Ca}$ is important because of its role in bones, teeth, muscles system and heart functions. $\mathrm{Ca}$ deficiency can lead to low bone mass (osteopemia), bone fractures, numbness and tingling in the fingers and abnormal heart rhythms. All the present studied plants show satisfactory level of $\mathrm{Ca}$ accumulation as in earlier reports (Abdul Ghani et al., 2012 and Shirin K et al.,2010) .

\section{Conclusion}

The medicinal plants investigated contain trace elements namely manganese, iron, copper, zinc, potassium and calcium of which potassium and calcium are major elements. The concentration (ppm) of the elements in the plants studied was found to be as follows: manganese (10 to 1800), iron (27 to 836), copper (6 to 140 ) and zinc (10 to160) and potassium (14120 to 76950) and calcium (1660 to 32030). From the comparison of the results with the defined permissible concentration limits, it was concluded that the levels of trace element contents in the locally available medicinal plants under investigation fall around the permissible range with the exception of Alpinia zerumbet with regard to its extremely high Mn content.

\section{Acknowledgement}

The authors are thankful to the staff of the Tandetron Accelerator, NCCCM for their constant support and assistance. The authors are also grateful to the Ministry of Science \& Technology, Department of Science \& Technology, Government of India, Technology Bhavan, New Delhi 110016 for the financial assistance.

\section{References}

[1]. Abdul Ghani, Zulfaqar Ali, Muhammad Ishtiaq, Mehwish Maqbool and Saira Parbeen (2012). Estimation of macro and micro nutrients in some important medicinal plants of Soon Valley, District Khushab, Pakistan.African Journal of Biotechnology, 11(78):14386-14391.

[2]. Basgel S. Erdemoglu SB (2006) Determination of minerals and trace elements in some medicinal herbs and their infusions consumed in Turkey. Sci.Total Env. 359: 82-89.

[3]. Calixto, B.J., 2000. Efficacy, safety, quality control, marketing and regulatory guidelines for herbal medicines (phytotherapeutic agents). Brazilian journal of Medical and Biological research, 33(2): 179-189.

[4]. FAO/WHO., 1984.Contaminants. In codex Alimentarius, vol.XVII, Edison 1. FAO/WHO, Codex Alimentarius Commision, Rome

[5]. Jabeen, S., M.T. Shah, S. Khan and M.Q. Hayat, 2010. Determination of major and trace elements in ten important folk therapeutic plants of Haripur basin, Pakistan, Journal of Medicinal Plants Research, 4(7): 559-566.

[6]. Khan, S.A., L. Khan, I. Hussain, K.B. Marwat and N.Ashtray, 2008. Profile of heavy metals in selected medicinal plants. Pakistan journal of weed science and research, 14(1-2):101-110. 
[7]. Koe H. Sari H (2009) Trace metal contents of some medicinal aromatic plants and soil samples in the Mediterranean region, Turkey J. Appl. Chem. Res. 8: 52-57.

[8]. Ozcan MM, Akbulut M (2007). Estimation of minerals, nitrates and nitrite contents of medicinal and aromatic plants used as spices, condiments and herbal tea. Food Chem. 106:852-858.

[9]. Sharma KR Agarwal M Marshall MF( 2009 ) Heavy metals in vegetables collected from production and market sites of a tropical urban area of India. Food Chem Toxicol 47: 583-591.

[10]. Sheded GM, Pulford ID , Hamed IA (2006). Presence of major and trace elements in seven medicinal plants growing in South Eastern Desert, Egypt J. Arid. Env $66: 210-217$.

[11]. Shirin K, Imad Shafic S, Fatima K (2010). Determination of major and trace elements in the indigenous medicinal plants Withania somnifera and their possible correlation with therapeutic activity. J. Saudi Chem Soc. 14: 97-100.

[12]. Ullah, R., J.A. Khader, I. Hussain, N.M. AbdElsalam, M. Talha and N. Khan, 2012. Investigation of macro and micro nutrients in selected medicinal plants. African Journal of Pharmacy and Pharmacology, 6(25): 1829-1832.

[13]. WHO (1992) Cadmium. Environmental Health Criteria Vol. 134 Geneva.

[14]. WHO, 2005. Quality Control Methods for Medicinal plant Materials, Revised Geneva. 